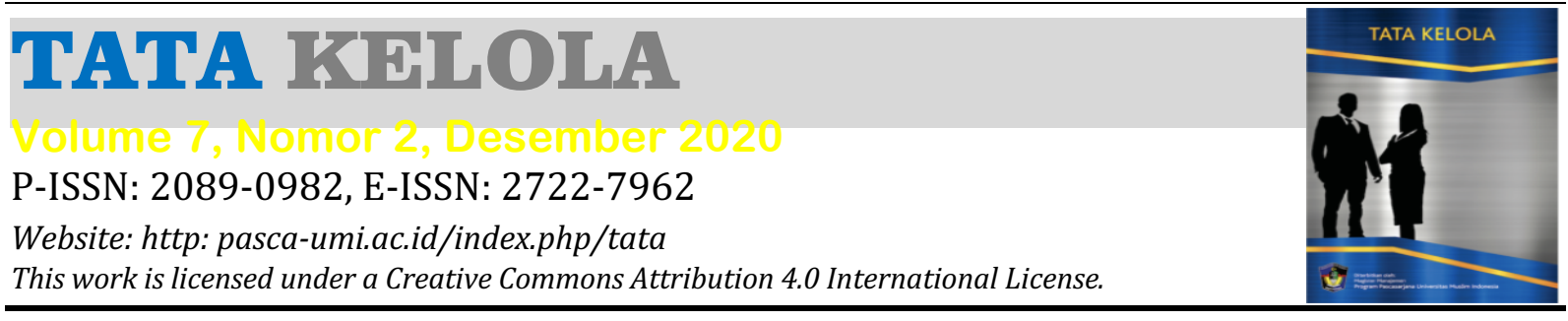

\title{
Pengaruh kualitas Layanan Dan KuaLitas Produk Terhadap Kepuasan Pelanggan
}

\author{
Mirna Ayu Noviaㅁ, Baharuddin Semmaila², Imaduddin ${ }^{3}$ \\ 12,3, Magister Manajemen, Universitas Muslim Indonesia. \\ ${ }^{1}$ Koresponden Penulis, E-mail: mirnaayu.novia@gmail.com
}

\begin{abstract}
ABSTRAK
Tujuan penelitian ini adalah untuk mengetahui pengaruh kualitas layanan melalui (Tangible, Reliability, Responsiveness, assurance, Emphaty) terhadap kepuasan pelanggan. Untuk mengetahui pengaruh kualitas produk melalui (fungsi, fitur, keandalan, kesesuaian, usia produk, estetika, perceived, quality) terhadap kepuasan pelanggan. Untuk mengimplementasikan tujuan tersebut maka digunakan analisis deskriptip. uji asumsi klasik, uji validitas dan uji reliabilitas. Hasil penelitian menemukan bahwa kualitas layanan melalui bukti fisik, kehandalan, daya tanggap, jaminan dan empati berpengaruh postif dan signifikan terhadap kepuasan pelanggan. Kualitas produk melalui fungsi, fitur, keandalan, kesesuaian, usia produk, estetika, perceived, quality berpengaruh positif dan signifikan terhadap kepuasan pelanggan . dari kedua variabel bebas yang digunakan dalam menetukan tingkat kepuasan pelanggan, ternyata variabel kualitas produk yang mempunyai pengaruh dominan dalam meningkatkan kepuasan pelanggan pada Toko Novia di Pusat Grosir Butung Makassar.
\end{abstract}

Kata Kunci: Kualitas Layanan; Kualitas Produk; Kepuasan Pelanggan

\begin{abstract}
The purpose of this research is to find out the effect of quality of service through (Tangible, Reliability, Responsiveness, assurance, Emphaty) on customer satisfaction. To know the effect of product quality through (functionality, features, reliability, suitability, product age, aesthetics, perceived, quality) on customer satisfaction. To implement these objectives, descriptive analysis is used. classic assumption test, validity test and reliability test. The results found that the quality of service through physical evidence, reliability, responsiveness, assurance and empathy had a significant effect on customer satisfaction. Product quality through functionality, features, reliability, suitability, product age, aesthetics, perceived, quality has a positive and significant effect on customer satisfaction. of the two free variables used in improving customer satisfaction levels, it turns out that product quality variables have a dominant influence in improving customer satisfaction at Novia Store in Butung Makassar Wholesale Center.
\end{abstract}

Keywords: Service Qualit; Product Quality; Customer Satisfaction 


\section{PENDAHULUAN}

Perkembangan teknologi informasi menjadikan persaingan bisnis dalam lingkungan global semakin kompetitif dan semakin sulit. Banyaknya bermunculan pesaing baru dalam industri yang sama, menjadi ancaman bagi perusahaan yang sedang menjalankan bisnisnya. Kepuasan konsumen atau customer satisfaction merupakan salah satu tujuan yang ingin di capai semua perusahaan dalam penetapan strategi dan taktik pemasaran yang di buat. Kepuasan konsumen adalah persepsi konsumen bahwa harapannya telah terpenuhi atau terlampui dengan membeli dan atau menggunakan produk tersebut. Semua perusahaan akan berlomba-lomba untuk menciptakan kepuasan konsumen karena jika konsumen puas, maka konsumen akan semakin setia dengan perusahaan tersebut. Jika konsumen puas, akan semakin banyak uang yang dibelanjakan konsumen dan konsumen terus akan membelanjakannya. Dengan demikian omzet penjualan akan terus meningkat sehingga secara otomatis keuntungan perusahaan pun semakin besar.

Bila ditinjau dari sudut pandang perusahaan, ada banyak cara yang dilakukan perusahaan. Salah satu cara yang efektif dalam melakukan diferensiasi (perubahan) adalah melalui peningkatan mutu dan kualitas pelayanan yang diberikan. Suatu perusahaan yang mampu bersaing di dunia usaha yaitu perusahaan yang dapat menyediakan produk yang berkualitas. Sehingga adanya perbaikan yang dilakukan perusahaan terutama dalam kualitas pelayanannya. Hal ini dapat menjadikan perusahaan cukup baik dalam bisnis utama suatu perusahaan. Kepuasan konsumen menjadi suatu sasaran strategis agar perusahaan dapat tumbuh dan berkembang serta tetap eksis dalam menghadapi perubahan dapat tumbuh dan berkembang serta tetap eksis dalam menghadapi perubahan persaingan yang ketat seperti sekarang. Keputusan perusahaan melakukan tindakan perbaikan pelayanan yang sistematis merupakan paying yang menentukan dalam menindaklanjuti complain konsumen dari suatu kegagalan sehingga pada akhirnya mampu mengikat loyalitas konsumen (Elu, 2005). Kepuasan pelanggan menjadi parameter penting sehingga bisnis dapat terus berkelanjutan.

Menurut para akademisi, kepuasan pelanggan merupakan konstruk yang berdiri sendiri dan dipengaruhi oleh kualitas layanan (Oliver, 1980). Semakin tingginya tingkat persaingan, akan menyebabkan konsumen menghadapi lebih banyak alternatif produk, harga dan kualitas yang bervariasi, sehingga konsumen akan selalu mencari nilai yang dianggap paling tinggi dari beberapa produk (Kotler, 2005). Kualitas yang rendah akan menimbulkan ketidakpuasan pada konsumen, tidak hanya konsumen yang datang tersebut tapi juga berdampak pada orang lain. Karena konsumen yang kecewa akan bercerita paling sedikit kepada 15 orang lainnya. Dampaknya, calon pelanggan akan menjatuhkan pilihannya kepada pesaing (Lupiyoadi dan Hamdani, 2006). Upaya perbaikan system kualitas pelayanan lebih efektif bagi keberlangsungan bisnis. Saat ini, banyak perusahaan yang semakin memahami arti penting dari kepuasan konsumen dan menjalankan strategi guna memberikan kepuasan bagi konsumennya. Kepuasan pelanggan merupakan faktor sangat penting bagi keberadaan, keberlangsungan, dan perkembangan perusahaan. (Bahari, et.al, 2020) kepuasan konsumen merupakan evaluasi pembeli dimana sekurang-kurangnya memberikan hasil (outcome) sama atau melampui harapan 
konsumen. Sedangkan ketidakpuasan timbul apabila hasil yang di peroleh tidak memenuhi harapan pelanggan.

Salah satu faktor yang mempengaruhi kepuasan konsumen adalah kualitas pelayanan. Goetsch dan Davis (1994) mendefenisikan kualitas pelayanan merupakan suatu kondisi dianamis yang berhubungan dengan produk jasa, manusia, proses dan lingkungan yang mampu memenuhi dan atau melebihi harapan konsumen. Faktor kedua yang mempengaruhi kepuasan konsumen adalah harga. Harga adalah jumlah uang (kemungkinan ditimbang beberapa barang) yang dibutuhkan untuk memperoleh bebrapa kombinasi sebuah produk dan pelayananan yang menyertainya (Kotler dan Keller, 2007:156). Menurut Kotler dan Keller (2009:50), pelanggan membentuk ekspektasi jasa dari banyak sumber, seperti pengalaman masa lalu, berita dari mulut ke mulut, dan iklan. Secara garis besar pelanggan akan membentuk ekspektasi jasa yang rendah jika pengalaman masa lalu yang dialaminya juga rendah, perkataan dari teman, dan sebagainya. Untuk dapat memuaskan pelanggan, kinerja dari jasa yang diberikan oleh perusahaan haruslah sesuai atau lebih tinggi dari eskpektasi pelanggan.

Menurut Kotler (Susanto, 2005) kepuasan adalah tingkat perasaan seseorang setelah membandingkan kinerja (atau hasil) yang dirasakan dibandingkan dengan harapannya, sedangkan menurut Sangadji dan Sophia (dalam Andrieani, 2016:28) kepuasan diartikan sebagai adanya kesempatan antara kinerja produk dan pelayanan yang diterima dengan kinerja produk dan pelayanan yang diharapkan konsumen. Factor utama penentu kepuasan pelanggan adalah persepsi pelanggan terhadap kualitas jasa.

Berdasarkan pendapat para ahli tersebut dapat disimpulkan kepuasan pelangga adalah evaluasi pelanggan terhadap kinerja produk maupun jasa yang diterima terhadap ekspektasi kinerja dari produk maupun jasa yang diterimnya terhadap ekspektasi kinerja dari produk ataupun jasa dari pelanggan. Pada umumnya ekspektasi pelanggan adalah harapan atau keyakinan dari pelanggan akan kinerja suatu produk atau jasa yang akan diterimanya bila ia mengomsumsi produk atau jasa yang akan diterimanya bila ia mengomsumsi produk atau jasa tersebut. Sementara kinerja dari produk atau jasanya ialah persepsi dari pelanggan tersebut mengenai apa yang ia terima setelah mengomsumsi produk atau jasa tersebut.

Faktor lain yang dapat mempengaruhi kepuasan konsumen adalah kualitas produk. Menurut Kotler dan Armstrong (2004) menyatakan bahwa kualitas produk berhubungan erat dengan kemampuan produk untuk menjalankan fungsinya, termasuk keseluruhan produk, keandalan, ketepatan, kemudahan pengoperasian dan perbaikan, dan atribut bernilai lainnya. Jadi kualitas produk merupakan sekumpulan ciri dan karakteristik dari barang yang mempunyai kemampuan untuk memenuhi kebutuhan, merupakan suatu pengertian gabungan dari keandalan, ketepatan, kemudahan, pemeliharaan serta atribut-atribut lainnya dari suatu produk. Apabila pelanggan merasa puas terhadap suatu produk yang di beli, akan menimbulkan kesetiaan pelanggan sehingga membuat pelanggan melakukan pembelian ulang di masa yang akan datang. Banyaknya pesaing tidak menghalangi Toko Novia untuk tetap bertahan, bahkan mampu berkembang pesat sampai sekarang ini. Memberikan pelayanan yang memuaskan bagi pelanggan adalah visi dari Toko Novia untuk tetap 
bertahan bahkan berkembang diantara pesaingnya. Berikut ini adalah tabel yang menunjukkan jumlah pelanggan Toko Novia selama bulan Maret 2019 sampai Februari 2020.

Tabel 1

Data Jumlah Pelanggan Toko Novia

Bulan Maret 2019 sampai Februari 2020

\begin{tabular}{ccc} 
Bulan & $\begin{array}{c}\text { Jumlah Pelanggan } \\
\text { Toko Novia }\end{array}$ & Kurang Puas \\
\hline Maret & 453 & 2 \\
\hline April & 527 & 1 \\
\hline Mei & 642 & 8 \\
\hline Juni & 382 & 1 \\
\hline Juli & 318 & 4 \\
\hline Agustus & 351 & 8 \\
\hline September & 453 & 2 \\
\hline Oktober & 527 & 1 \\
\hline November & 487 & 3 \\
\hline Desember & 576 & 1 \\
\hline Januari & 290 & 2 \\
\hline Februari & 371 & 6
\end{tabular}

Berdasarkan Tabel 1 menunjukkan bahwa jumlah pelanggan Toko Novia cukup banyak. Namun hal tersebut tidak menjamin bahwa pelanggan akan selalu loyal pada Toko Novia. Karena di balik banyaknya pelanggan masih ada saja pelanggan yang kembali karena kurang puas. rata-rata dalam 1 bulan ada pelanggan yang merasa kurang puas. Toko Novia mempunyai tantangan pada umumnya. Pelanggan akan membandingkan layanan dan dukungan yang diberikan Toko Novia dengan layanan dan dukungan yang mereka harapkan. Jika pelanggan merasa puas, maka pelanggan akan kembali lagi ke Toko Novia dan menjadi pelanggan setia serta akan menceritakan pengalaman tersebut kepada orang lain. Sehingga jumlah pelanggan akan terus bertambah. Tetapi jika pelanggan merasa tidak puas, maka pelanggan akan mengeluhkan ketidakpuasannya tersebut kepada pihak Toko Novia. Keluhan atau ketidak puasan pelanggan seharusnya di tanggapi pihak Toko dengan mengambil langkah-langkah yang diperlukan, sehingga pelanggan akan merasa puas dengan layanan dan dukungan yang diberikan pihak Toko.

Manajemen pemasaran adalah penganaliasaan, perencanaan, pelaksaan, dan pengawasan program-program yang ditujukan untuk mengadakan pertukaran dengan pasar yang dituju dengan maksud untuk mencapai tujuan organisasi dalam memenuhi kebutuhan dan keinginan pasar tersebut serta menentukan harga, mengadakan komunikasi, dan distribusi yang efektif untuk memberitahu, mendorong, serta melayani pasar (Dharmmesta dan Irawan, 2001). Menurut Kotler dan Keller (2009) nilai yang dipersiapkan pelanggan adalah selisih antara penilaian pelanggan perpektif atas semua manfaat dan biaya dari suatu karyawan terhadap alternatifnya. Sementara menurut Lovelock dan Wright (2007) nilai pelanggan adalah jumlah seluruh manfaat yang dipahami atau dipersepsikan (nilai kotor) dikurangi 
jumlah semua biaya yang dipahami. Makin besar perbedaan positif diantara keduanya, makin besar nilai pelanggannya.

\section{METODE PENELITIAN}

Pendekatan dalam penelitian ini menggunakan pendekatan kuantitatif, dimana dalam proses penelitian yang digunakan berdasarkan teori yang relevan dengan permasalahan yang diteliti untuk menemukan solusi dalam permasalahan tersebut. Penelitian ini dilakukan di toko novia di pusat grosir butung Makassar yang beralamat di Jalan pasar butung, Kecamatan wajo, kota Makassar, Sulawesi Selatan. Populasi dari penelitian ini ialah konsumen yang berlanja pada took novia di pasar butung, karna banyak pelanggan maka penelitian mengambil metode Probability Sampling, yaitu Teknik pengambilan sampel yang tidak memberi peluang / kesempatan sama bagi setiap unsur atau anggota populasi untuk dipilih menjadisampel (Sugiyono,2010). Sampel dalam penelitian sebanyak 50 orang. Adapun metode analisis dengan pengujian hipotesis ialah analisis deskriptif, uji validitas dan uji reliabilitas dan asusmsi klasik.

\section{HASIL PENELITIAN DAN PEMBAHASAN}

\section{Hasil}

\section{A. Uji Normalitas}

Uji normalitas bertujuan untuk menguji apakah dalam model regresi, variable pengganggu atau residual memiliki distribusi normal. Untuk melihat normalitas residual menggunakan grafik histogram yang membandingkan antara data observasi dengan distribusi yang mendekati distribusi normal. Jika data menyebar sekitar garis diagonal dan mengikuti arah garis diagonal atau garis histogramnya menunjukkan pola distribusi normal, maka model regresi memiliki asumsi normalitas. Berdasarkan olah data Hasil pengujian normalitas data dengan menggunakan Normal PPlot dapat dilihat pada gambar berikut.

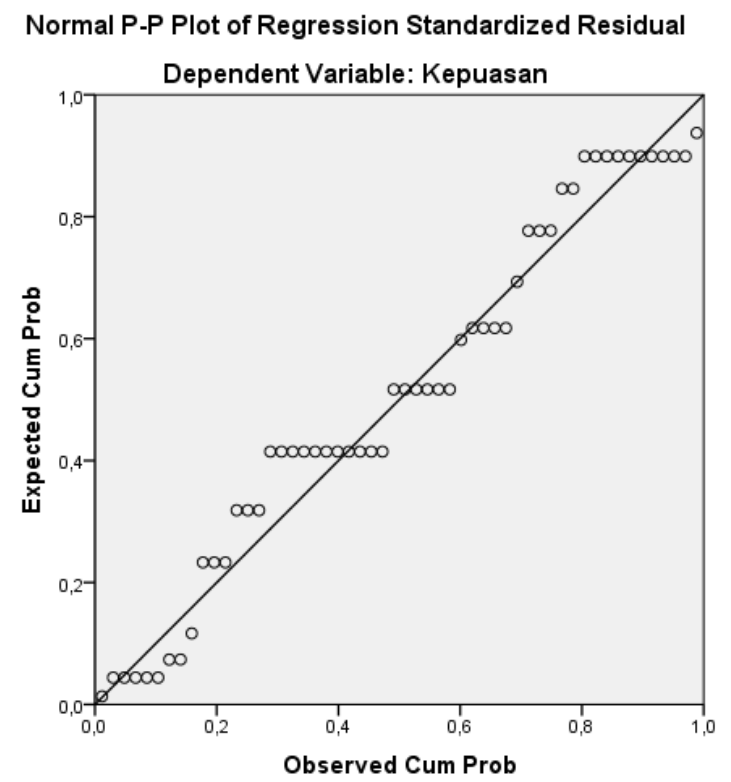


Pada gambar 2 tersebut menunjukkan bahwa titik-titik data berada di sekitar garis diagonal dan mengikuti arah garis diagonal. Dengan demikian, dapat disimpulkan bahwa data dalam penelitian ini sudah terdistribusi normal atau sudah memenuhi asumsi normalitas.

\section{B. Uji Heteroskedastisitas}

Uji heteroskedastisitas bertujuan untuk menguji apakah dalam model regresi terjadi ketidaksamaam varian dari residual satu pengamatan ke pengamatan yang lain. Model regresi yang baik adalah yang homoskedastisitas atau tidak terjadi heteroskedastisitas. Deteksi ada atau tidaknya heteroskedastisitas dapat dilihat dari ada tidaknya pola tertentu pada grafik scatterplot. Jika tidak pola yang jelas, serta titiktitik menyebar di atas dan di bawah angka 0 pada sumbu $Y$, maka tidak terjadi heteroskedastisitas. Berikut merupakan hasil uji heteroskedastisitas dengan menggunakan grafik scatterplot.

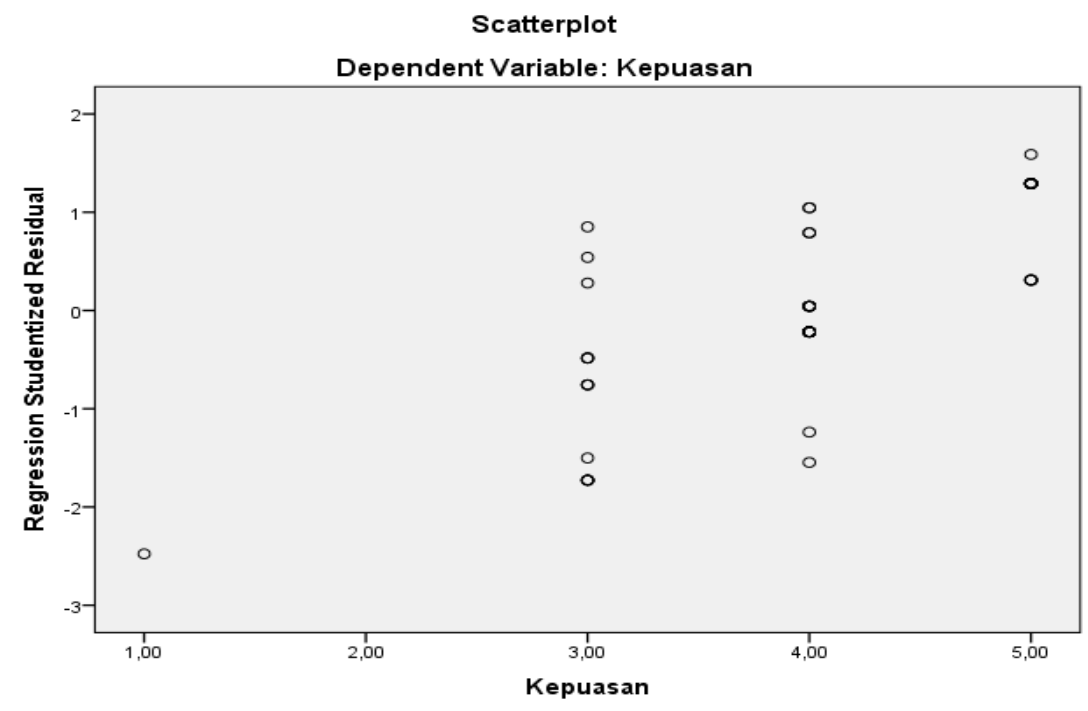

Berdasarkan gambar 3 di atas dapat dilihat bahwa titik-titik data menyebar secara acak dan tidak membentuk suatu pola, baik di atas maupun di bawah angka 0 pada sumbu Y. Jadi, dapat disimpulkan bahwa model regresi dalam penelitian ini tidak mengalami masalah heteroskedastisitas.

\section{Uji Multikolinearitas}

Uji multikolinearitas bertujuan untuk menguji apakah dalam model regresi ditemukan adanya korelasi antar variabel bebas. Model regresi yang baik seharusnya tidak terjadi korelasi di antara variabel bebas. Pengujian multikolonieritas dilihat dari besaran VIF (Variance Inflation Factor) dan tolerance.. Regresi yang bebas dari problem multikolonieritas apabila nilai VIF $<10$ dan tolerance $>0.1$, maka data tersebut dikatakan tidak ada multikolonierita. Hasil uji multikolonieritas terhadap data untuk pengujian hipotesis ditunjukkan pada tabel 10 berikut berikut: 


\section{Coefficients $^{\mathrm{a}}$}

\begin{tabular}{ll|l|l} 
& & \multicolumn{2}{|c}{ Collinearity Statistics } \\
\multicolumn{2}{l|}{ Model } & Tolerance & \multicolumn{1}{c}{ VIF } \\
\hline 1 & (Constant) & & \\
\cline { 2 - 3 } & Kualitas Pelayanan &, 711 & 1,406 \\
\cline { 2 - 3 } & Kualitas Produk &, 711 & 1,406 \\
\hline
\end{tabular}

a. Dependent Variable: Kepuasan

Berdasarkan analisis data pada tabel 10 di atas menunjukkan hasil uji multikolonieritas dengan VIF berkisar antara 1.406, Sedangkan nilai tolerance berkisar antara 0.711. Dari hasil pengujian tersebut dapat disimpulkan bahwa semua variable independen tidak memiliki masalah multikolonieritas.

\section{Analisis Regresi Linear Berganda}

Analisis regresi linear berganda digunakan apabila ingin meramalkan pengaruh dua variabel atau lebih variabel bebas $(X)$ terhadap sebuah variabel terikat $(Y)$ atau untuk membuktikan bahwa terdapat atau tidak terdapatnya hubungan antara dua variabel atau lebih variabel bebas dengan sebuah variabel terikat. Analisis regresi linear berganda dapat dilihat pada Tabel 11 berikut:

\section{Coefficients $^{a}$}

\begin{tabular}{|c|c|c|c|c|}
\hline \multirow{2}{*}{\multicolumn{2}{|c|}{ Model }} & \multicolumn{2}{|c|}{$\begin{array}{l}\text { Unstandardized } \\
\text { Coefficients }\end{array}$} & \multirow{2}{*}{$\begin{array}{c}\text { Standardized } \\
\text { Coefficients } \\
\text { Beta }\end{array}$} \\
\hline & & $B$ & Std. Error & \\
\hline \multirow[t]{3}{*}{1} & (Constant) & ,833 & ,102 & \\
\hline & $\begin{array}{l}\text { Kualitas } \\
\text { Pelayanan }\end{array}$ & ,473 & ,129 & ,316 \\
\hline & Kualitas Produk & ,555 & , 147 & ,470 \\
\hline
\end{tabular}

Tabel 11 di atas menunjukkan hasil olah data regresi atas pengaruh Kualitas layanan dan Kualitas produk terhadap kepuasan konsumen pada toko novia di pusat grosir butung. Hasil persamaan regresi linear berganda dari model penelitian ini yaitu: 


$$
\mathrm{Y}=0,833+0,473 \times 1+0,555 \mathrm{X} 2
$$

Berdasarkan hasil persamaan regresi linearberganda tersebut diuraikan sebagai berikut:

1. Konstanta bo $=0,833$ menyatakan bahwa jika variabel independen Kepuasan pelanggan di toko novia konstan, maka peningkatan penjualan akan sebesar $\mathrm{Y}$ $=0,833$

2. $\mathrm{b} 1=0,473$ menunjukkan bahwa, jika variabel Kualitas layanan ditingkatkan, maka peningkatan penjualan akan meningkat sebesar 0,473 dengan asumsi variabel Bukti fisik, Keandalan, Daya tanggap, jaminan dan Empaty konstan.

3. $\mathrm{b} 2=0,555$ menunjukkan bahwa, jika variabel Kualitas Produk ditingkatkan, maka peningkatan penjualan akan meningkat sebesar 0,555 dengan asumsi variabel Hasil produk, ciri-ciri atau keistimewahan tambahan, kehandalan, kesesuaian dengan spesifikasi, daya tahan, kegunaan, estetika, kualitas yang dirasakan konstan.

Berdasarkan uraian diatas dari ketiga variabel independen tersebut, maka dapat disimpulkan bahwa variabel yang paling berpengaruh terhadap kepuasan konsumen pada toko novia di pusat grosir butung adalah variabel Kualitas Produk (X2).

\section{E. Uji Hipotesis}

Hipotesis diuji dengan menggunakan uji signifikansi parameter individual (Uji Parsial). Uji ini digunakan untuk menguji tingkat signifikansi pengaruh variabel independen yang terdiri dari pemasaran digital melalui websites, social media dan email marketing terhadap variabel dependen yaitu peningkatan penjualan secara parsial atau secara sendiri-sendiri. Pengambilan keputusan dilakukan berdasarkan perbandingan nilai $t$ hitung masing-masing koefisien $t$ regresi dengan $t$ tabel sesuai dengan tingkat signifikansi yang digunakan yaitu 0,05. Hasil uji signifikansi parameter individual ( Uji t ) disajikan pada tabel 12 berikut ini

\begin{tabular}{|c|c|c|c|c|c|c|}
\hline & & & & \multicolumn{3}{|c|}{ Coefficients $^{a}$} \\
\hline & & $\begin{array}{r}\text { Unstar } \\
\text { Coef }\end{array}$ & $\begin{array}{l}\text { dardized } \\
\text { ficients }\end{array}$ & \multirow{2}{*}{$\begin{array}{c}\text { Standardiz } \\
\text { ed } \\
\text { Coefficients } \\
\text { Beta }\end{array}$} & \multirow[b]{2}{*}{$\mathrm{T}$} & \multirow[b]{2}{*}{ Sig. } \\
\hline \multicolumn{2}{|c|}{ Model } & $B$ & Std. Error & & & \\
\hline \multirow[t]{4}{*}{$\overline{1}$} & (Constant) & ,833 & ,102 & & 8,166 &, 000 \\
\hline & Kualitas & ,473 & ,129 & ,316 & 3,666 & ,005 \\
\hline & Pelayanan & & & & & \\
\hline & Kualitas Produk &, 555 &, 147 & ,470 & 3,776 & ,003 \\
\hline
\end{tabular}

Dependent Variable: Kepuasan

Untuk mengetahui besarnya pengaruh masing-masing variabel independen $(X 1, X 2)$ terhadap variabel dependen (Y) secara parsial, dapat dilakukan dengan membandingkan nilai t-hitung $>$ t-tabel (0.102) dan $a<0,05$ sebagaimana yang terlihat 
pada tabel sebelumnya. Untuk mengetahui lebih jelasnya dapat diuraikan sebagai berikut:

1. Hasil pengujian terhadap variabel Kualitas pelayanan (X1) menunjukkan bahwa nilai nilai t-hitung 3,666 > t-tabel 0,102 dan tingkat signifikan sebesar 0,005 < 0,05. Hasil penelitian menunjukkan bahwa variabel Kualitas pelayanan (X1) berpengaruh secara positif dan signifikan terhadap kepuasan konsumen. Dengan demikian hipotesis yang diajukan diterima.

2. Hasil pengujian terhadap variabel social media (X2) menunjukkan bahwa nilai nilai t-hitung 3,776 > t-tabel 0,102 dan tingkat signifikan sebesar 0,03<0,05. Hasil penelitian menunjukkan bahwa variabel kualitas produk (X2) berpengaruh secara positif dan signifikan terhadap kepuasan konsumen. Dengan demikian hipotesis yang diajukan diterima.

\section{Pembahasan}

Berdasarkan tujuan penelitian ini yaitu untuk mengetahui pengaruh variabel kualitas pelayanan dan kualitas produk terhadap kepuasan konsumen pada toko novia di pusat grosir butung makassar. Setelah dilakukan uji hipotesis secara parsial, maka kedua variabel independen yaitu kualitas layanan (X1), kualitas produk (X2), berpengaruh positif dan signifikan terhadap kepuasan konsumen pada toko novia di pusat grosir butung Makassar. Adapun pembahasan mengenai pengaruh variabel kualitas pelayanan dan kualitas produk terhadap kepuasan konsumen pada toko novia di pusat grosir butung makassar adalah sebagai berikut.

1. Pengaruh Kualitas Layanan terhadap Kepuasan Konsumen pada toko Novia di Pusat Grosir Butung Makassar.

Hasil penelitian hipotesis menunjukkan bahwa terdapat pengaruh positif dan signifikan antara kualitas layanan terhadap kepuasan konsumen pada toko novia di pusat grosir Butung Makassar. Hasil ini diperoleh melalui hasil perhitungan nilai $\mathrm{t}$ hitung sebesar 3,666 yang lebih besar dari nilai $t$ tabel sebesar 0,102 dengan taraf signifikansi 0,005 yang lebih kecil dari 0,05 sehingga hipotesis pertama diterima (H1 diterima). Kemudian dari hasil uji parsial yang telah dilakukan yang menunjukkan bahwa kualitas pelayanan yang terdiri dari bukti fisik, kehandalan, daya tanggap, jaminan dan empati memberikan pengaruh nyata dalam meningkatkan kepuasan konsumen.

Indikator yang dominan dalam membentuk variabel kualitas layanan adalah jaminan, artinya jaminan cukup terpenuhi kepada setiap pelanggan yang berbelanja di toko novia. Kemudian di ikuti daya tanggap, artinya pelanggan puas dengan kesigapan karyawan dalam melayani pelanggan, namun masih perlu di tingkatkan yaitu empati agar dapat mendukung kualitas layanan dalam meningkatkan kepuasan pelanggan di toko novia. Dimana semakin baik pemberian kualitas pelayanan yang meliputi bukti fisik, kehandalan, daya tanggap, jaminan dan empati maka akan dapat memberikan pengaruh yang berarti/nyata dalam meningkatkan kepuasan pelanggan pada Toko Novia di Pusat Grosir Butung Makassar. Meskipun demikian, kelima indikator dari variabel kualitas layanan tersebut, baik uji validitas maupun uji realibilitas menunjukkan nilai $r$-hitung $>r$ tabel yang berarti setiap butir pernyataan dari veriabel kualitas layanan yang digunakan dalam penelitian ini adalah valid dan reliabel. 
Hasil penelitian ini sesuai dengan penelitian yang dilakukan oleh Aprilia Nia Fardiani (2013) yang berjudul analisis pengaruh kualitas pelayanan, harga, dan promosi terhadap kepuasan pelanggan Dyriani Bakery dan Café Pandanaran Semarang. Dari hasil analisis diketahui secara keseluruhan bahwa kualitas pelayanan, harga dan promosi berpengaruh positif terhadap kepuasan pelanggan. Sedangkan penelitian yang dilakukan penelitian yang di lakukan oleh Ryan Nur Haryanto, dalam jurnalnya yang berjudul "analisis Pengaruh Harga, Produk, Kebersihan, dan Kualitas Pelayanan Terhadap Kepuasan Pelanggan (studi kasus pada restoran mamamia Cabang Mrican Semarang)." Dengan alat analisa yang digunakan: Uji Validitas, Uji Reliabilitas, Uji asumsi Klasik, Analisis regresi berganda. Dengan Hasil Dimana Pengujian Hipotesis Variabel Harga, Produk, kebersihan, kualitas layanan, kepuasan pelanggan menunjukan bahwa keempat variable independen yang di teliti terbukti secara signifikan mempengaruhi variable independen yang diteliti terbukti secara signifikan mempengaruhi variable dependen kepuasan pelanggan.

Penelitian yang dilakukan oleh Tirra Ammerinda (2017) dengan judul pengaruh kualitas produk dan kualitas pelayanan terhadap kepuasan konsumen pada klinik kecantikan nadindra di Bandar Lampung. Dengan hasil menunjukkan bahwa kualitas produk dan kualitas pelayanan berpengaruh positif terhadap kepuasan konsumen dengan hasil perhitungan variabel kualitas produk dan kualitas pelayanan mempengaruhi variabel kepuasan konsumen 64,6\% dan sisanya 35,4\% dipengaruhi oleh variabel lainnya yang tidak diteliti pada penelitian ini.

2. Pengaruh Kualitas Produk terhadap Kepuasan Konsumen pada toko Novia di Pusat Grosir Butung Makassar.

Hasil penelitian hipotesis menunjukkan bahwa terdapat pengaruh positif kualitas produk terhadap kepuasan konsumen pada Toko Novia di Pusat Grosir Butung Makassar dan menunjukkan hasil yang signifikan. Hasil ini diperoleh melalui hasil perhitungan nilai t hitung sebesar 3,776 yang lebih besar dari nilai t tabel sebesar 0,102 dengan taraf signifikansi 0,03 yang lebih kecil dari 0,05 sehingga hipotesis kedua diterima (H2 diterima) sehingga dapat ditarik kesimpulan bahwa kualitas produk berpengaruh positif dan signifikan terhadap kepuasan konsumen pada Toko Novia di Pusat Grosir Butung Makassar.

Pengujian ini secara statistik dapat membuktikan bahwa variabel Kualitas produk meliputi Fungsi, Fitur, Keandalan, Kesesuaian, usia produk, estetika, perceived, quality, berpengaruh positif dan signifikan terhadap kepuasan pelanggan berpengaruh positif dan signifikan terhadap kepuasan konsumen. Hasil pengujian menunjukkan bahwa kualitas produk memperoleh nilai paling tinggi dengan tingkat signifikansi yang paling berpengaruh diantara variabel lainnya. Hal ini menunjukkan bahwa kepuasan konsumen yang menjadi prioritas utama dilihat dari produk yang di tawarkan oleh toko novia, konsumen juga lebih sering melihat dan memeriksa kualitas dari produk yang kami tawarkan untuk menjadi kepuasan konsumen belanja dan kembali ke toko novia. Hal ini berarti menandakan betapa pentingnya membangun kualitas produk dalam mencapai kepuasan pelanggan.

Pernyataan yang dominan dalam membentuk variabel kualitas produk terhadap kepuasan konsumen pada toko novia adalah pernyataan pelanggan mengenai barang yang diperlihatkan baik, dan diikuti pernyataan toko novia memiliki barang dengan 
kualitas terbaik. Sedangkan pernyataan barang yang dijual bervariasi memberikan proporsi terkecil dalam variabel kualitas produk, sehingga perlu ditingkatkan. Meskipu demikian, indikator dari variabel kualitas produk tersebut, baik uji validitas maupun uji reliabilitas menunjukkan nilai $r$-hitung $>r$ tabel yang berarti setiap butir pernyataan dari kualitas produk yang digunakan dalam penelitian ini adalah valid dan reliable.

Hasil penelitian ini sesuai dengan penelitian yang dilakukan oleh Sri Rahayu Tri Astuti (2013) dengan judul analisis pengaruh kulitas produk, harga, lokasi dan kualitas pelayanan terhadap minat beli konsumen (study pada warung makan bebek gendut semarang). Dengan hasil analisis di ketahui secara keseluruhan bahwa semua variable berpengaruh positif terhadap minat beli ulang konsumen. Selain itu hasil penelitian ini menjadi bukti empiris yang sangat relefan dengan kondisi penjualan dalam mencapai kepuasan konsumen saat sekarang.

Penelitian yang dilakukan oleh Kartika Nur Rahmawati (2017) dengan judul pengaruh kualitas produk dan pelayanan terhadap kepuasan konsumen di kedai bangsawan Klaten. Dengan hasil menunjukkan kualitas produk di kedai bangsawan klaten dalam kategori baik, kualitas pelayanan di kedai bangsawan klaten dalam kategori baik, kualitas produk memiliki pengaruh yang signifikan $(32,10)$ terhadap kepuasan konsumen di kedai bangsawan klaten, kualitas pelayanan memiliki pengaruh yang signifikan $(32,70)$ terhadap kepuasan konsumen di kedai bangsawan klaten. kualitas produk dan pelayanan secara bersama-sama memiliki pengaruh yang signifikan $(64,80)$ terhadap kepuasan konsumen di kedai bangsawan klaten.

\section{KESIMPULAN}

Berdasarkan hasil penelitian dan pembahasan, maka dapat ditarik kesimpulan sebagai berikut (1) Berdasarkan hasil penelitian, maka dapat disimpulkan Kualitas layanan meliputi tangible, reliability, responsiveness, assurance, dan emphaty memiliki pengaruh positif dan signifikan terhadap kepuasan konsumen pada Toko Novia di pusat Grosir butung Makassar. Hal ini berarti apabila kualitas layanan ditingkatkan maka kepuasan konsumen Toko Novia di pusat Grosir Butung Makassar akan meningkat. (2) Berdasarkan hasil penelitian, maka dapat disimpulkan Kualitas produk meliputi Fungsi, Fitur, Keandalan, Kesesuaian, usia produk, estetika, perceived, quality memiliki pengaruh positif dan signifikan terhadap kepuasan konsumen pada Toko Novia di pusat Grosir butung Makassar. Hal ini berarti apabila kualitas produk ditingkatkan maka kepuasan konsumen Toko Novia di pusat Grosir Butung Makassar akan meningkat. (3) Berdasarkan hasil penelitian, maka dapat disimpulkan kualitas layanan dan kualitas produk secara bersama-sama memiliki pengaruh positif dan signifikan terhadap kepuasan konsumen pada Toko Novia di pusat Grosir butung Makassar. Hal ini berarti apabila kualitas layanan dan kualitas produk secara bersama ditingkatkan maka kepuasan konsumen Toko Novia di pusat Grosir Butung Makassar akan meningkat. Saran dari penelitian ini ialah Perusahaan dapat mengambil langkah konkrit untuk mempercepat peningkatan penjualan dapat terealisasi, perusahaan dapat merencanakan sistem marketing berbasis online dengan persiapan yang matang. 


\section{DAFTAR PUSTAKA}

Ammerinda, T. (2017). Pengaruh Kualitas Produk Dan Kualitas Pelayanan Terhadap Kepuasan Konsumen Pada Klinik Kecantikan Nadindra Di Bandar Lampung.

Fardiani, A.N. (2015). Pengaruh Kualitas Pelayanan Dan Promosi Terhadap Kepuasan Konsumen Pt. Pos Indonesia (Persero) Lumajang (Doctoral dissertation, STIE Widya Gama Lumajang).

Astuti, S. R. T. (2013). Studi Tentang Keputusan Pembelian Smartphone Pada Kelas Konsumen Baru Di Kota Semarang. Fokus Ekonomi: Jurnal Ilmiah Ekonomi, $8(1)$.

Bahari, A. F., Basalamah, J., Murfat, M. Z., Hasan, A., \& Basalamah, A. Customer Value, Brand Image And Promotion; Analysis Of Purchasing Decisions (Case Of Silk Fabrication).

Elu, B. (2005). Manajemen Penanganan Komplain Konsumen di Industri Jasa. Jurnal ilmu Administrasi dan Organisasi

Kotler, P. Dkk. (2007). Manajemen Pemasaran. Jilid 1. Edisi 12, Terjemahaan Benyamin Molan. Indeks. Jakarta.

Kotler, P. (2009). Manajemen Pemasaran. Jilid 1. Edisi 13, Erlangga. Jakarta.

Kotler, P. (2016). Marketing Management 16 edition. New Jersey: Pearson.

Lovelock, C.H dan Wright, L.K. (2007). Manajemen Pemasaran Jasa, Edisi Bahasa Indonesia, PT. Indeks. Jakarta.

Lupiyoadi, R \& Hamdani, A. (2006), Manajemen Pemasaran Jasa, Salemba Empat.

Oliver, R.L (1980). A Cognitive Model of The Antecedents and Consequences of satisfaction decisions. Jurnal of Marketing Research, 17.

Rahmawati, K. N. (2017). Pengaruh Kualitas Produk Dan Pelayanan Terhadap Kepuasan Konsumen Di Kedaibangsawan Klaten. 